\title{
ORBITAL AND FORAMEN MAGNUM VARIABLES FOR SEX DETERMINATION IN EGYPTIANS USING COMPUTED TOMOGRAPHIC IMAGES
}

\author{
Shireen Ragab slima ${ }^{1}$ and Eman Ragab ${ }^{2}$ \\ 1 Forensic Medicine and Clinical Toxicology Department, Faculty of Medicine, Menoufia \\ University
}

2 Radiodiagnosis Department, Faculty of Medicine, Menoufia University

\begin{abstract}
Introduction: Sex determination is one of the principle indicators of identity. The skull is the second best part of the skeleton to be used for sex determination after the pelvis. Sex determination from cranial fragments becomes essential especially when only a part of the skull is brought for identification.

Aim: The present study was aimed to demonstrate the sexual dimorphism of the orbit and the foramen magnum (FM) in a sample of Egyptian population in order to increase the number of parameters used for identification, and by consequence, the accuracy when these parameters are combined with each other. Subjects and Methods: The present study was done on 300 cranial CT scans of known gender, 168 males and 132 females, with age ranged from 18 to 65 years, who presented to the Department of Radiodiagnosis, Menoufia University for head computed tomography (CT) as indicated in the course of their management for diagnostic purpose from January to October 2019. The data were tabulated and statistically analyzed. Results: The results showed that the orbital height, width and index differences between males and females were statistically significant $(\mathrm{P}<0.001)$. Significant difference was also observed in FM transverse diameter, FM anteroposterior diameter and FM area. Tetragonal shape of FM was the most common in both sexes of the study sample. Conclusion: The present study shows that Foramen magnum and orbital variables can be considered along with the other parameters of the skull for sex determination in forensic analysis.
\end{abstract}

Keywords: Skull, Sex determination, Orbital index

\section{INTRODUCTION}

Skull is one of the most preferred bones for identification and sexual dimorphism. The Sex of an individual can be identified accurately in $90 \%$ of cases using skull alone (Dhanwate and Ankushrao, 2017). The determination of sex is statistically the most important criterion of identification, as it immediately excludes half the population. Sexing of the skull using morphological marks is more subjective and depends on experience of the investigator but, methods based on measurements and morphometry are accurate and reliable (Vedanayagam and Sathyamurthy 2015). Metric analyses on the radiographs are often used because of their objectivity and accuracy (Attia et al., 2018).

The orbit is the bony socket in the skull where the eye and its appendages are situated. The relationship between the 
orbital height and orbital width is given by orbital index (OI) which varies in different races and in different regions within the same race (Ranasinghe et al., 2018). This index is useful in forensic medicine for skull classification and also for better surgical approach and for evaluation of craniofacial syndromes and post traumatic deformities (Patil et al., 2014; Botwe et al., 2017).

Foramen Magnum is the largest foramen in the base of the skull which gives passage to vital structures such as medulla oblongata continues as spinal cord along with meninges, spinal arteries, vertebral arteries and spinal accessory nerve (Devadas et al., 2017).

Skull base is well-protected and has a substantial significance in sex identification in cases of significantly disrupted remains due to the resistant nature in explosions, fire trauma, and aircraft accidents. Foramen Magnum is an important landmark of the skull base and has a favorable anatomical position as it is protected from direct impact because it is covered by soft tissue and the skeleton of the head, so it is preserved for forensic examination (Jaitley et al., 2016; Sampada et al., 2017).

\section{AIM OF THE WORK}

The present study was designed to compare various foramen magnum and orbital variables between male and female subjects using computed tomography to assess their usefulness in sex determination in a sample of Egyptian population.

\section{MATERIAL AND METHODS}

A retrospective study was done on 300 CT scans comprising of 168 males and 132 females, with age ranged from 18 to 65 years, who presented to the Department of Radiodiagnosis, Menoufia University. The lower limit of age was fixed as 18 years because the sexual characteristics of the bone do not begin to manifest themselves until the stage of puberty is attained (Vedanayagam and Sathyamurthy, 2015). The study was carried out in an ethical manner following guidelines set by the Ethical Committee of Faculty of Medicine, Menoufia University.

Systematic random sampling method was used to select 300 normal adult head CT scans; the cases had been referred to the CT Unit for head CT scan from January to October 2019. Prior the sampling, CT scan images of subjects with craniofacial malformations, fractures or previously operated were excluded from the study.

All head CT scan images were observed by a trained radiologist in multiplanar reformat and 3D reconstruction. Measurements were done using the electronic caliper of the Toshiba Asteion CT equipment.

Orbital Height is the maximum vertical distance between the superior and inferior orbital margins. Orbital Width is measured from the frontal process of the zygomatic arch to the frontal process of the maxilla (figure 1). Orbital index (OI) was calculated using a standard formula: Orbital height/Orbital width X 100 (Ranasinghe, et al. 2018). Bilateral measurements from all CT scans were recorded in millimeters and tabulated.

The maximum transverse diameter (TD) was measured between the lateral margins of the FM at the point of greatest lateral curvature. The maximum anteroposterior diameter (APD) of the foramen magnum was measured from the basion (the midpoint of the anterior margin of the FM) to the opisthion (the midpoint of the posterior margin of the FM), perpendicularly to the previous line (figure 2). 
FM index (FMI): (transverse diameter /anteroposterior diameter) x 100

The shape of the foramen magnum was observed and recorded. The different shapes of the foramen magnum were classified as oval, round, egg, tetragonal, pentagonal, and hexagonal (figure 3).

The area of the foramen magnum was calculated using the Radinsky's formula according to Radinsky, (1967):

$$
\mathrm{A}=1 / 4 \times \pi \times \mathrm{TD} \times \mathrm{APD}
$$

Where: $\pi=22 / 7$, mathematical constant.

\section{STATISTICAL ANALYSIS:}

Descriptive statistics; mean, stander deviation SD and range were calculated in both sexes. The differences of means between the male and female were compared for significance using the Student t-test. $\mathrm{Z}$ test was used to compare two proportions in two groups. The difference was considered significant at $\mathrm{P} \leq 0.05$. All the statistical analyses were performed using the Statistical Package for Social Sciences (SPSS Inc. Released 2015. IBM SPSS statistics for windows, version 23.0, Armnok, NY: IBM Corp.).

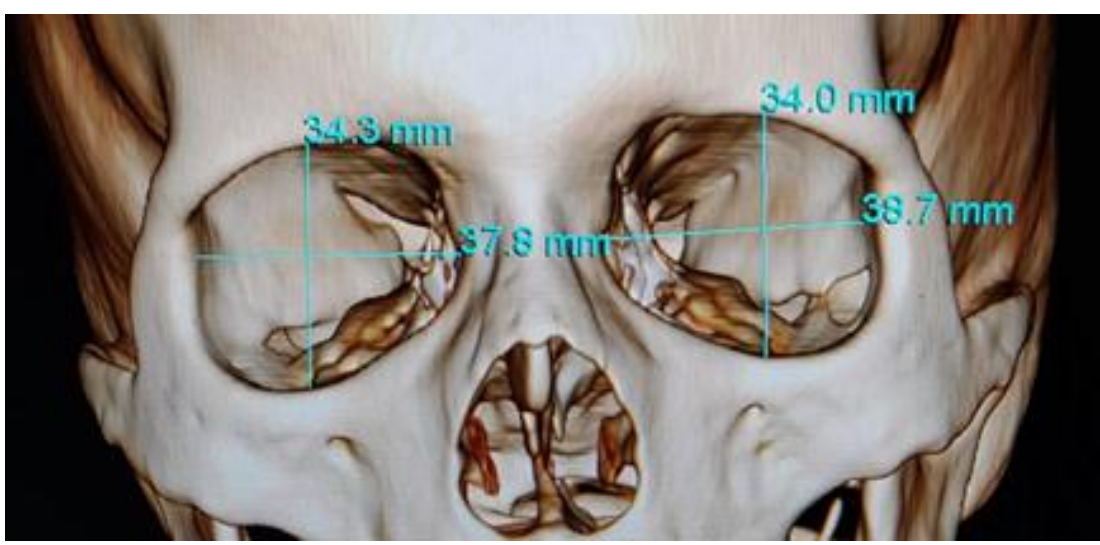

Figure 1: 3D reconstruction of $\mathrm{CT}$ head demonstrated the measurement of the height and width of both orbits.

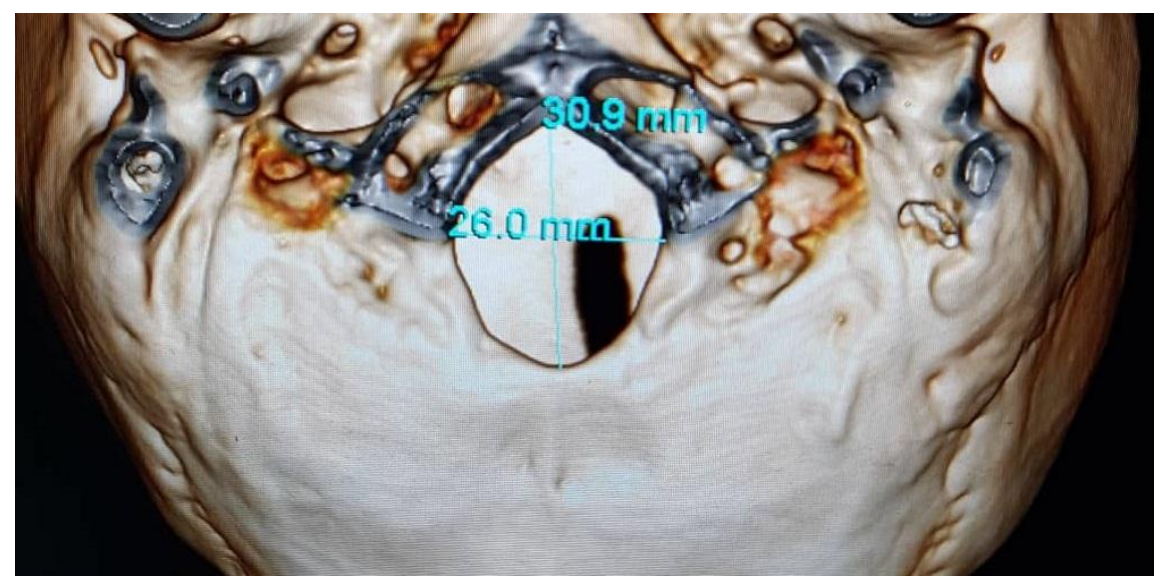

Figure 2: 3D reconstruction of CT head declared the measurement of anteroposterior and transverse diameters of the foramen magnum. 


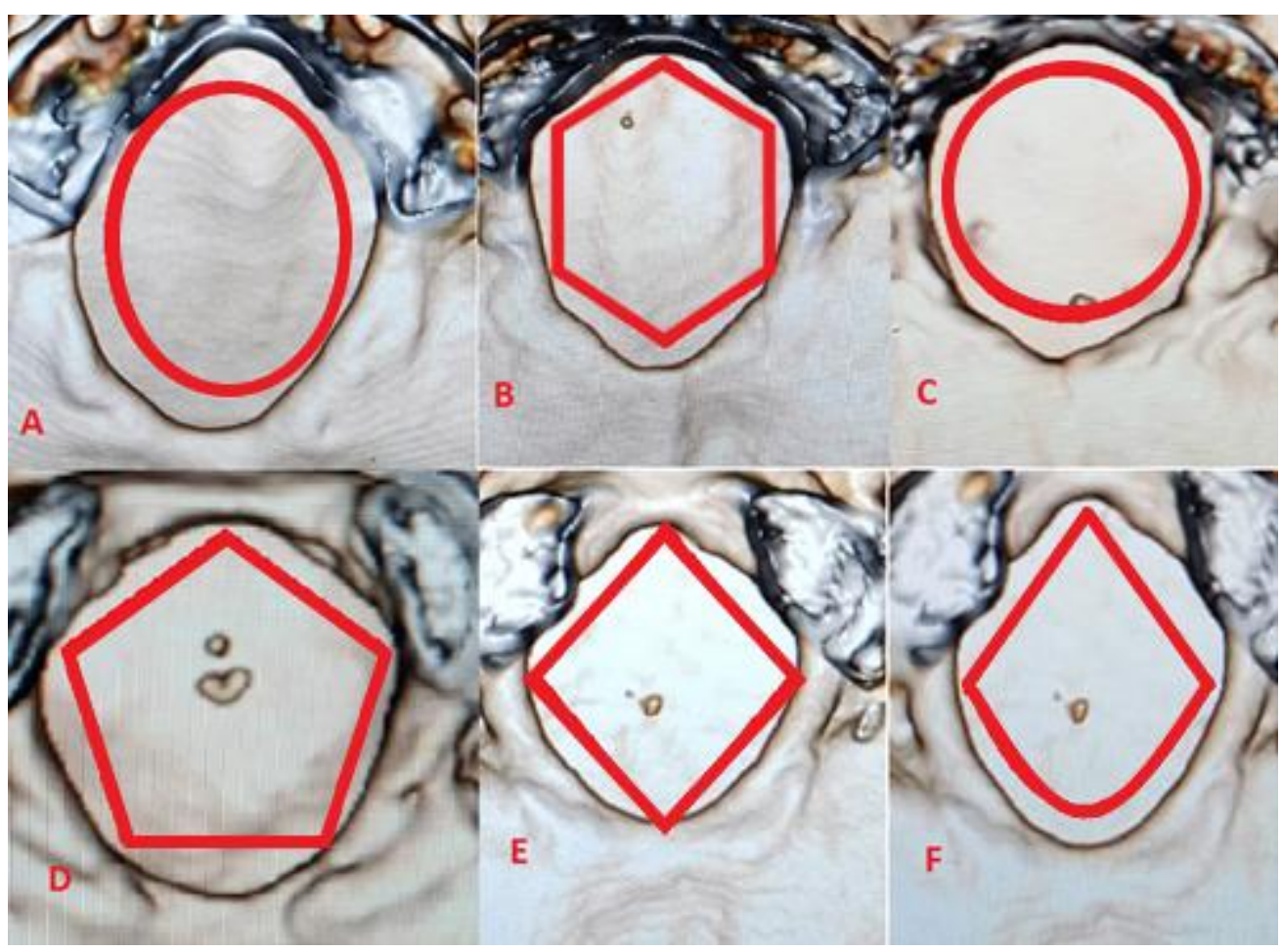

Figure 3: Different shapes of the foramen magnum, $A=$ oval, $B=$ hexagonal, $C=$ rounded, $D=$ pentagonal, $\mathrm{E}=$ tetragonal, $\mathrm{F}=$ egg shaped.

\section{RESULTS}

Table (1) showed range and mean of the right orbital height, width, and index in both genders of CT scans while table (2) showed the results on the left side, where the mean and standard deviation of orbital height for male were observed as $33.29 \pm 2.05 \mathrm{~mm}$ and $33.59 \pm 1.84 \mathrm{~mm}$ in male right and left orbital cavities respectively. It was slightly higher in females as the values for females were $34.61 \pm 1.99 \mathrm{~mm}$ and $34.40 \pm 1.75 \mathrm{~mm}$ in the right and left sides respectively.

Regarding orbital width, it was measured as $39.11 \pm 2.03 \mathrm{~mm}$ and $39.22 \pm$ $2.06 \mathrm{~mm}$ in male right and left orbital cavities respectively. In females, it was reported as $37.01 \pm 1.75$ in the right orbits and $37.07 \pm 1.62$ in the left orbits.
The mean OI in males was calculated as $85.16 \pm 4.05$ for the right side and $86.66 \pm$ 4.35 for the left side. The mean values calculated for females were $92.72 \pm 2.53$ and $92.82 \pm 2.80$ in the right and left sides respectively. The difference between male and female indices was statistically significant $(P<0.001)$.

Table (3) showed foramen magnum parameters in both genders of CT scans, where the mean antero-posterior diameter and standard deviation of the foramen magnum in males and females is $36.74 \pm$ $2.82 \mathrm{~mm}$ and $32.18 \pm 2.29 \mathrm{~mm}$ respectively. The t-test calculated a p-value $<0.001$.

Regarding the TD of the foramen magnum, the mean value for males was $31.09 \pm 1.77 \mathrm{~mm}$, while for females; it was $27.20 \pm 1.76 \mathrm{~mm}$. When the mean values of 
males and females were compared, the difference was highly significant $(\mathrm{P}<0.001)$.

The index of FM was calculated; it ranged from 70.5 to 98.4 in males with a mean value $84.91 \pm 5.87$ and for females, it ranged from 66.1 to 95.9 with a mean value $84.91 \pm 7.40$. The difference was not statistically significant.

The range of FM area recorded for males was $644.8-1125.7 \mathrm{~mm}^{2}$ and for females was $561.1-876.0 \mathrm{~mm}^{2}$. The mean values calculated for males and females were $898.89 \pm 103.08$ and $687.79 \pm 69.74$ $\mathrm{mm}^{2}$, respectively. The difference was highly significant $(\mathrm{P}<0.001)$.
The results concerning the shape of foramen magnum were showed in table (4).

Tetragonal shape was the most common in both sexes of the study sample. It represented $32.1 \%$ of male $\mathrm{CT}$ scans and $31.8 \%$ of female CT scans, followed by, egg shaped in males (17.9 \%). The egg and hexagonal shaped FM was significantly more frequent in males than females (P $<0.05)$.

Oval and pentagonal shaped FM was present in $25 \%$ of female CT scans for each. The difference was significantly higher than their presence in males $(\mathrm{P}<0.05)$. The least common was the Hexagonal shape in both sexes.

Table (1): Range and mean \pm SD of the right orbital height, width, and index in both genders of CT scans

\begin{tabular}{|c|c|c|c|c|c|c|}
\hline \multirow[t]{2}{*}{ Variable } & \multicolumn{2}{|c|}{ Male CT scans } & \multicolumn{2}{|c|}{ Female CT scans } & \multirow[t]{2}{*}{ t-test } & \multirow[t]{2}{*}{$P$ value } \\
\hline & Range & Mean \pm SD & Range & Mean \pm SD & & \\
\hline $\begin{array}{l}\text { Orbital height } \\
(\mathrm{mm})\end{array}$ & $27.9-39.0$ & $33.29 \pm 2.05$ & $30.8-38.3$ & $34.61 \pm 1.99$ & 5.61 & $<0.001$ \\
\hline $\begin{array}{l}\text { Orbital width } \\
(\mathrm{mm})\end{array}$ & $34.8-44.5$ & $39.11 \pm 2.03$ & $32.0-40.0$ & $37.01 \pm 1.75$ & 9.43 & $<0.001$ \\
\hline Orbital index & $67.5-92.6$ & $85.16 \pm 4.05$ & $85.8-97.6$ & $92.72 \pm 2.53$ & 18.74 & $<0.001$ \\
\hline
\end{tabular}

Descriptive variable statistics

SD: standard deviation

Statistical analysis using Student t-test

$P$ significant $\leq 0.05$ 
Table (2): Range and mean \pm SD of the left orbital height, width, and index in both genders of CT scans

\begin{tabular}{|c|c|c|c|c|c|c|}
\hline \multirow[t]{2}{*}{ Variable } & \multicolumn{2}{|c|}{ Male CT scans } & \multicolumn{2}{|c|}{ Female CT scans } & \multirow[t]{2}{*}{ t-test } & \multirow[t]{2}{*}{$P$ value } \\
\hline & Range & Mean \pm SD & Range & Mean \pm SD & & \\
\hline $\begin{array}{l}\text { Orbital height } \\
(\mathrm{mm})\end{array}$ & $30.0-37.0$ & $33.59 \pm 1.84$ & $30.6-38.2$ & $34.40 \pm 1.75$ & 3.83 & $<0.001$ \\
\hline $\begin{array}{l}\text { Orbital width } \\
(\mathrm{mm})\end{array}$ & $34.8-44.5$ & $39.22 \pm 2.06$ & $31.7-39.7$ & $37.07 \pm 1.62$ & 9.83 & $<0.001$ \\
\hline Orbital index & $31.0-44.4$ & $86.66 \pm 4.35$ & $\begin{array}{l}86.80- \\
96.5\end{array}$ & $92.82 \pm 2.80$ & 16.40 & $<0.001$ \\
\hline
\end{tabular}

Descriptive variable statistics

SD: standard deviation

Statistical analysis using Student t-test

$\mathrm{P}$ significant $\leq 0.05$

Table (3): Foramen magnum parameters in both genders of CT scans

\begin{tabular}{|c|c|c|c|c|c|c|}
\hline \multirow[t]{2}{*}{ Variable } & \multicolumn{2}{|c|}{ Male CT scans } & \multicolumn{2}{|c|}{ Female CT scans } & \multirow[t]{2}{*}{ t-test } & \multirow[t]{2}{*}{$P$ value } \\
\hline & Range & Mean \pm SD & Range & Mean \pm SD & & \\
\hline $\begin{array}{l}\text { Anteroposterior } \\
\text { diameter }(\mathrm{mm})\end{array}$ & $31.0-44.4$ & $36.74 \pm 2.82$ & $27.6-37.5$ & $32.18 \pm 2.29$ & 15.07 & $<0.001$ \\
\hline $\begin{array}{l}\text { Transverse } \\
\text { diameter }(\mathrm{mm})\end{array}$ & $26.3-33.9$ & $31.09 \pm 1.77$ & $24.0-31.0$ & $27.20 \pm 1.76$ & 18.81 & $<0.001$ \\
\hline index & $70.5-98.4$ & $84.91 \pm 5.87$ & $66.1-95.9$ & $84.91 \pm 7.40$ & 0.00 & 1.00 \\
\hline Area $\left(\mathrm{mm}^{2}\right)$ & $\begin{array}{l}644.8- \\
1125.7\end{array}$ & $\begin{array}{ll}898.89 & \pm \\
103.08 & \end{array}$ & $\begin{array}{l}561.1- \\
876.0\end{array}$ & $\begin{array}{ll}687.79 & \pm \\
69.74 & \end{array}$ & 20.17 & $<0.001$ \\
\hline
\end{tabular}

Descriptive variable statistics

SD: standard deviation

Statistical analysis using Student t-test

$\mathrm{P}$ significant $\leq 0.05$ 
Table (4): The number and percentages of various shapes of FM in both genders of CT scans

\begin{tabular}{|c|c|c|c|c|c|c|}
\hline \multirow[t]{2}{*}{ Shape } & \multicolumn{2}{|c|}{ Male CT scans } & \multicolumn{2}{|c|}{ Female CT scans } & \multirow[t]{2}{*}{$P$ value } & \\
\hline & No. & $\%$ & No. & $\%$ & & \\
\hline Oval & 24 & 14.3 & 33 & 25.0 & 0.028 & $\mathrm{P}<0.05$ \\
\hline Egg & 30 & 17.9 & 12 & 9.1 & 0.026 & $\mathrm{P}<0.05$ \\
\hline Round & 18 & 10.7 & 9 & 6.8 & 0.330 & $\mathrm{P}>0.05$ \\
\hline Tetragonal & 54 & 32.1 & 42 & 31.8 & 0.944 & $\mathrm{P}>0.05$ \\
\hline Pentagonal & 24 & 14.3 & 33 & 25.0 & 0.028 & $\mathrm{P}<0.05$ \\
\hline Hexagonal & 18 & 10.7 & 3 & 2.3 & 0.009 & $\mathrm{P}<0.05$ \\
\hline
\end{tabular}

Descriptive variable statistics

Statistical analysis using $\mathrm{Z}$ test

P significant $\leq 0.05$

\section{DISCUSSION}

Measures of the skull are crucial to forensic and anthropologic investigations. They are also relevant to clinical, surgical and anatomical studies (Pires et al., 2016). Using computerized tomography images provides noninvasive and accurate method for observing different variables of the skull (Chandramani et al., 2015).

In the present study, the results showed that males exhibited greater mean values for all the measurements except for orbital height that was slightly increased in females. This made females to have rounder orbits. Orbits pertaining to female skulls are usually rounder, while orbits belonging to male skulls generally have a square format (Kumar and Nagar, 2014). The study done by Botwe et al., (2017) reported also higher values of orbital height in females and higher orbital width in males. The orbital index of the Egyptians examined in the current study showed values calculated as $85.16 \pm 4.05$ for males and for females $92.72 \pm 2.53$ which differed when compared with other population groups. Ebeye and Otikpo, (2013) studied the orbital index in Nigeria and recorded $78.15 \pm 0.82$ for males and $78.99 \pm 0.38$ for females. It was found $79.29 \pm 5.65$ for males and $84.39 \pm 5.59$ for females in Sri Lanka (Lal et al., 2016). It was also examined in Ghanaians using CT scan by Botwe et al., (2017). Their results reported that the mean orbital index was $80.52 \pm 4.66$ in males and $82.15 \pm 3.83$ in females. All these studies indicated some level of racial and ethnic variation in the OI of various population groups.

In the present study, the mean OI was greater in females than males. Higher OI in females has been reported in a previous Egyptian study by Fetouh and Mandour, (2014). The Orbital index determines the shape of the face as larger orbital indices will have narrow faces (Divya et al., 2018). 
The difference between male and female orbital indices was statistically significant. Studies done by Jain et al., (2015) and Ranasinghe et al., (2018) observed similar findings in Indian skulls. So; it can be used for sex determination during forensic investigation. The use of this parameter is favoured because it is rapid, easy and can be measured both in the living and deceased. It is numerical and the development of a race and sex specific database can possibly be considered (Lal et al., 2016).

The present study revealed that the mean antero-posterior length of the foramen magnum for males was $36.74 \pm 2.82 \mathrm{~mm}$ and $32.18 \pm 2.29 \mathrm{~mm}$ for females, while the transverse diameter was $31.09 \pm 1.77 \mathrm{~mm}$ for males and $27.20 \pm 1.76 \mathrm{~mm}$ for females. It was lower than Indians (Jaitley et al., 2016). But, it was higher than the South African Black Population (Moodley et al., 2019). This may be due to racial differences and the ethnic variance.

In the present skull samples analyzed, mean values of antero-posterior length and transverse diameter of the foramen magnum in males were higher than in females. The mean of the area calculated using Radinsky's formula were higher in males. A significant sexual dimorphism was found in the measurements of the foramen magnum and the areas calculated $(p<0.001)$. These findings were also reported by Singh et al., (2017) and Moodley et al., (2019).

According to Radhakrishna et al., (2012), the FM measurements in males are greater because they tend to have larger heads than females. FM area was higher in males due to its correlation with both anteroposterior length and transverse diameters.

These findings were in accordance with the results of Chovalopoulou and Bertsatos, (2017) who studied the foramen magnum in Greeks and Mehta et al., (2019) in their Indian study who reported significant difference between males and females in all variables (Length, width and area of foramen magnum) except foramen magnum index.

Regarding the shape of the foramen magnum, Tetragonal shape was the most common in both sexes. In contrast, Devadas et al., (2017) studied the shape of foramen magnum in India and observed that the most common shape was oval in both sexes and the least common was the pentagonal shape.

Development of a particular shape of the FM is explained on the basis of the embryologic data. It may be caused by ossification of primordial cranial residues, which join the endochondral ossification points in different locations, resulting in various shapes (Sampada et al., 2017).

\section{CONCLUSION}

The present study suggests that orbit and foramen magnum regions exhibit sexual dimorphism in Egyptians and can be used in forensic medicine for sexual determination.

\section{REFERENCES}

Attia AM, Ghoneim M, and Elkhamary SM (2018): Sex discrimination from orbital aperture dimensions using computed tomography: Sample of Egyptian population, journal of Forensic Radiology and Imaging; (14): 32-38.

Botwe BO, Sule DS and Ismael A. (2017): Radiologic evaluation of orbital index among Ghanaians using CT scan, Journal of Physiological Anthropology, $36: 29$. 
Chandramani BM, Nairita $S$ and Ritika V. (2015): Morphological analysis of foramen magnum for gender determination by using computed tomography. J. Oral Med. Oral Surg. Oral Pathol. Oral Radiol.; 1(2):51-6.

Chovalopoulou $M$ and Bertsatos $A$. (2017): Estimating Sex of Modern Greeks Based on the Foramen Magnum Region, Journal of Anthropology; (3):17.

Devadas P, Rao M J, Yesender $M$, and Vinila S (2017): Study on the Morphometric Analysis of the Foramen Magnum as an Indicator for Sex Determination, Int $\mathrm{J}$ Anat Res; 5(3.1):4163-67.

Dhanwate AD and Ankushrao DS (2017) Assessment of indices used for sexual dimorphism of skull, Indian Journal of Clinical Anatomy and Physiology, 4(2):241-246.

Divya C, Swaroop Raj. B.V and Venkateshu K.V. (2018): Study of Orbital Morphometry in Dry Skulls of South Indian Origin. Int J Anat Res; 6(3.1):5449-5452.

Ebeye O.A and Otikpo O. (2013): Orbital Index in Urhobos of Nigeria. IOSR Journal of Dental and Medical Sciences; 8(2):51-53.

Fetouh FA and Mandour D. (2014): Morphometric analysis of the orbit in adult Egyptian skulls and its surgical relevance. Eur J Anat.; 18(4):303-15.

Jain D, Jasuja O.P, and Nath S. (2015): Determination of Sex Using Orbital Measurements, Ind. J. Phys. Anthrop. \& Hum. Genet. , 34(1): 97-108.

Jaitley M, Phulambrikar T, Kode M, Gupta A, and Singh SK. (2016):
Foramen magnum as a tool for sexual dimorphism: A cone beam computed tomography study. Indian J Dent Res; 27:458-62.

Kumar A and Nagar M. (2014): Morphometry of the Orbital Region: "Beauty is bought by judgement of the eyes". Int J Anat Res.; 2(3):566-70.

Lal N, Cornwall J, and Dias GJ. (2016): Orbital indices in a modern Sinhalese Sri Lankan population. Anatomy; 10(3):205-210.

Mehta M, Saini V, Patel M.N, and Menon S.K. (2019): Applicability and reliability of foramen magnum for sex determination in contemporary Western Indian population: A computed tomographic study, Journal of Forensic Radiology and Imaging; (17): 31-35.

Moodley M, Rennie C, Lazarus $L$ and Satyapal KS. (2019): The morphometry and morphology of the foramen magnum in age and sex determination within the South African Black population utilizing computer tomography (CT) scans. Int. J. Morphol., 37(1):251-257.

Patil GV, Shishirkumar, and Thejeswari. (2014): Study of orbital index in human dry skulls of south Indian origin. Int J Health Sci Res.; 4(9):125-128.

Pires LAS, Teixeira ÁR, Leite TFO, Babinski $M$ A and Chagas CAA. (2016): Morphometric aspects of the foramen magnum and the orbit in Brazilian dry skulls, Int J Med Res Health Sci.; 5(4):34-42.

Radhakrishna S.K, Shivarama C.H, Ramakrishna A, and Bhagya $B$. (2012): Morphometric Analysis of Foramen Magnum for Sex 
Determination in South Indian Population, Nitte University Journal of Health Science, 2(1):20-22.

Radinsky L. (1967): Relative brain size: a new measure. Science; 155:836- 838.

Ranasinghe AN, Babu KY, and Mohanraj KG (2018): Estimation of orbital index for gender determination, Drug Invention Today, 10 (12): 2408-2410.

Sampada P K, Poornima B, Mallikarjun M, Sakri SB. (2017): Morphometric and morphological a study of foramen magnum in dried human skull bones. Int J Anat Res; 5(2.1):3682-86.

Singh PK, Tamrakar D, Karki S, and Menezes RG. (2017): Determination of Sex from the Foramen Magnum using 3DCT: A Nepalese Study. Kathmandu Univ Med J; 57(1):61-5.

Vedanayagam $\mathbf{T}$ and Sathyamurthy V(2015): Sex Determination from Foramen Magnum Measurements - A Regional Study in Chennai, TN, Indian Journal of Forensic and Community Medicine, 2(3):179-181. 


\section{الملخص العربي}

متغيرات محجر العين و الثقبة العظمى لتحديد الجنس في المصريين بإستخدام صور الأشعة المقطعية

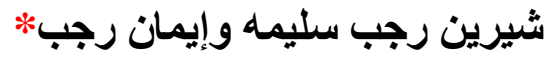

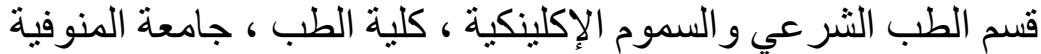

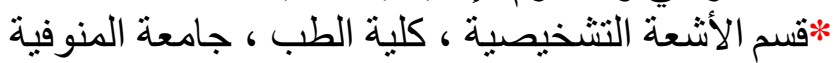

ملخص البحث:

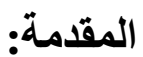

تحديد الجنس هو أحد المؤشرات الرئيسية للاستعر اف. وتعد الجمجمة ثاني أفضل جزء هُ من الهيكل العظمي

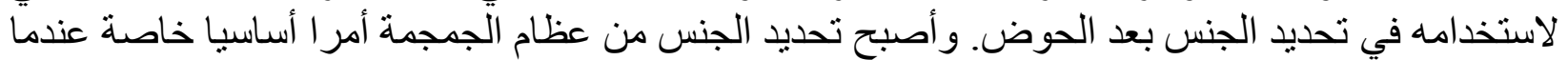
يتم إحضار جزء من الجمجمة فقط لتحديد هويتها.

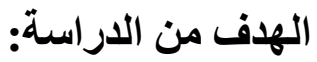

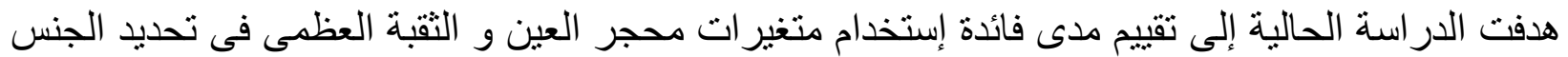

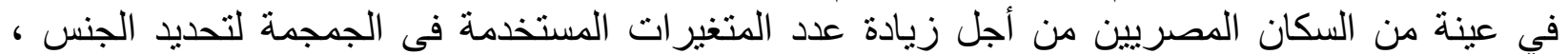

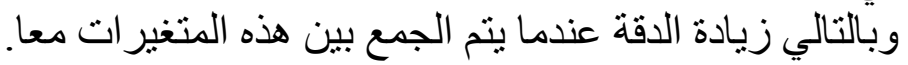

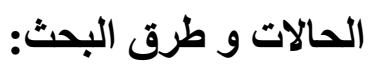

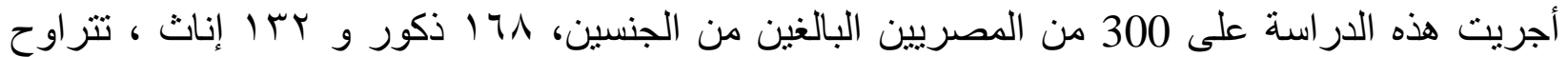

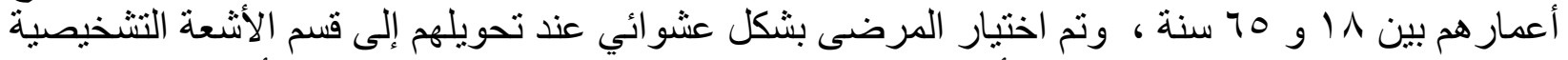

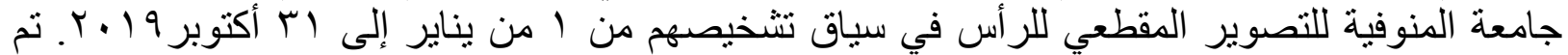

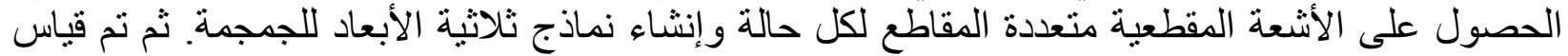
العديد من الأبعاد المتعلقة بمحجر العين والثقبة العظمى للجماجم الافتراضية. تم جدولة النتائج وتحليلها فياليا

إحصائيا.

النتائج

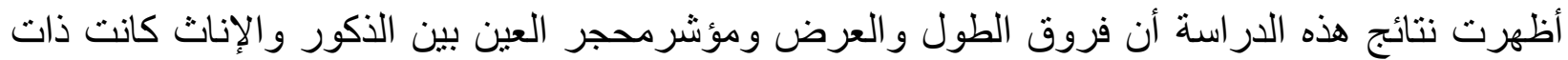

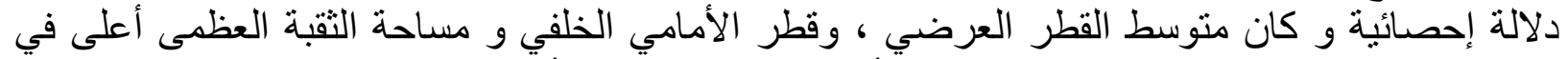
الذكور عنه في الإناث وكان الثكل رباعي الأبعاد للتقبة العظمى الأكثر شيو التها في كلا الجنسين من عينة

الإستنتاج و التوصية

أوضحت هذه الدراسة أنه يمكن إستخدام محجر العين و الثقبة العظمى إلى جانب غير ها من سمات الجمجمة لتحديد الجنس في مجال الطب الثر عي بإستخدام صور الأشعة المقطعية. 